\title{
PROFIL BERPIKIR SISWA DITINJAU DARI KREATIVITAS SISWA DALAM MENYELESAIAKAN KESEBANGUNAN DAN SIMETRI PADA BANGUN DATAR KELAS V SDN REJOMULYO KABUPATEN MAGETAN TAHUN AJARAN 2012/2013
}

\author{
${ }^{1}$ Anis Dwi Wijayanti, ${ }^{2}$ Sanusi, ${ }^{3}$ Benny Handoyo \\ ${ }^{1}$ Mahasiswa Prodi Matematika IKIP PGRI Madiun \\ ${ }^{2}$ Dosen Prodi Matematika IKIP PGRI Madiun \\ ${ }^{3}$ Dosen Prodi Matematika IKIP PGRI Madiun
}

\begin{abstract}
Abstrak. Penelitian ini bertujuan untuk meningkatkan kreativitas siswa dan mendeskripsikan kreativitas siswa dalam pembelajaran matematika khususnya pada sub bab kesebangunan dan simetri pada bangun datar.

Penentuan subjek di dalam penelitian ini berdasarkan nilai tes formatif yang dilakukan guru pada ulangan harian siswa kelas V SDN Rejomulyo yang berjumlah 16 siswa. Teknik pengambilan subjek menggunakan hasil tes formatif berupa ulangan harian yang dilakukan guru sehingga di diperoleh 2 siswa berkategori tinggi, 2 siswa berkategori sedang dan 2 siswa berkategori rendah. Teknik pengumpulan data dilakukan dengan metode tes dan wawancara. Analisis data yang digunakan adalah kegiatan mereduksi data, menampilkan data, dan melakukan verifikasi untuk membuat kesimpulan.

Hasil penelitian menunjukkan siswa kategori tinggi memiliki kecenderungan yang sedang dalam memeriksa proses dan hasil. Sedangkan untuk tahapan kreativitas yang lain siswa tergolong baik yaitu siswa mampu memahami masalah, merencanakan penyelesaian masalah dan melaksanakan rencana penyelesaian masalah dengan tepat dan benar dalam menyelesaikan masalah kesebangunan dan simetri pada bangun datar. Siswa kategori sedang memiliki kecenderungan yang sedang dalam tahapan kreativitas yaitu siswa mampu memahami masalah, merencanakan penyelesaian masalah, melaksanakan rencana penyelesaian masalah dan memeriksa proses dan hasil sehingga siswa dapat menyelesaikan soal kesebangunan dan simetri pada bangun datar dengan cukup runtut walaupun ada yang kurang tepat. Siswa kategori rendah memiliki kecenderungan yang sedang dalam menguraikan jawaban secara terperinci sedangkan untuk tahapan kreativitas yang lain siswa tergolong kurang yaitu siswa belum mampu memahami masalah, siswa belum mampu merencanakan penyelesaian masalah dan siswa belum mampu dalam melaksanakan rencana penyelesaian masalah kesebangunan dan simetri pada bangun datar dengan tepat dan benar.
\end{abstract}

Kata kunci: berpikir Kreatif, Kreativitas Siswa, Pemecahan Masalah Matematika.

\section{PENDAHULUAN}

Pada hakekatnya pendidikan adalah suatu proses pembelajaran pola pikir yang bertujuan untuk meningkatkan kualitis diri. Keberhasilan penyelenggaraan pendidikan merupakan tolak ukur pendidikan. Salah satu pendidikan yang ada adalah pendidikan formal. Pendidikan formal mencakup beberapa aspek salah satunya adalah aspek pendidikan matematika.

Pendidikan matematika merupakan pendidikan dasar karena matematika adalah ilmu yang dapat dipakai dalam berbagai aspek keseharian, misalnya untuk bertransaksi jual beli dipasar dan perkapalan. Melalui proses pembelajaran matematika, diharapkan siswa dapat berfikir logis, kritis, teliti, sistematis dan efektif. Selain itu berpikir kreativitas dalam pembelajaran matematika sangat dibutuhkan dalam memecahkan berbagai permasalahan matematika. Kreativitas diperlukan baik untuk menemukan pemecahan masalah yang baru maupun menemukan hubungan dengan pemecahan masalah yang telah ada. Pada hakikatnya, manusia mempunyai potensi untuk menjadi kreatif. Kenyataan di lapangan 
menunjukkan kepada kita bahwa kemampuan siswa akan lebih baik jika kemampuan kreatif mereka juga turut dilibatkan baik secara formal maupun informal. pada dasarnya, semua siswa memiliki potensi kreatif yang harus dikembangkan agar mereka mampu produktif dalam melaksanakan tugastugasnya. Kesadaran akan kemampuan kreativitas ini harus dibangun dan digali dalam kerangka yang lebih panjang demi menyongsong masa depan yaitu meningkatkan sumber daya manusia yang potensial guna memasuki abad 21 .

Kita semua menyadari akan pentingnya kreativitas sebagai motor bagi pendidikan. Pendidikan adalah penjemput hari depan bangsa agar lebih gemilang. Oleh karena itu, upaya-upaya menumbuhkan semangat dalam berkreasi perlu digalakkan. Mengapa? sebab maju mundurnya pendidikan sedikit banyak ditentukan oleh berhasil tidaknya kita mengembangkan kreativitas.

Ada beberapa penyelesaian cara di dalam ilmu matematika yang membutuhkann kreativitas khususnya untuk sekolah dasar salah satunya yaitu sub bab kesebangunan dan simetri pada bangun datar. Sub bab ini siswa dituntut untuk dapat kreatif, tanggap, dan imajinatif dalam menyelesaian permasalahan-permasalahan yang ada. Beberapa permasalahan tersebut diantaranya adalah kesulitan-kesulitan siswa dalam menganalisa beberapa bangun apakah bangun tersebut sebangun atau tidak selain itu banyak sekali siswa yang mengalami kesulitan dalam menentukan simetri putar maupun simetri lipat pada suatu bangun yang telah diketahui. Untuk menentukan simetri putar siswa sekolah dasar dituntut untuk dapat berimajinasi tinggi padahal kita tahu tidak semua anak dapat berimajinasi maupun membayangkan dalam menyelesaikan suatu persoalan.

Dari penjabaran tersebut penelitian ini bertujuan untuk meningkatkan kreativitas siswa dan mendeskripsikan kreativitas siswa dalam pembelajaran matematika khususnya pada sub bab kesebangunan dan simetri pada bangun datar. Dari pertimbangan tersebut maka penulis melakukan penelitian dengan judul profil berpikir siswa ditinjau dari kreativitas siswa sekolah dasar dalam menyelesaikan permasalahan kesebangunan dan simetri pada bangun datar sdn rejomulyo tahun ajaran 2012/2013.

Adapun rumusan masalah dalam penelitian ini meliputi apa saja prinsipprinsip berpikir kreatif itu, apa saja devinisi kreativitas itu, apa saja unsurunsur yang ada di dalam berpikir kreatif itu dan langkah-langkah seperti apakah yang diperlukan dalam memecahkan suatu masalah khusunya kesebangunan dan simetri pada bangun datar.

Berdasarkan rumusan masalah yang telah dibuat, maka tujuan penelitian ini adalah untuk mendekripsikan prinsip-prinsip kreativitas, untuk menjabarkan devinisi kreativitas menurut empat $\mathrm{P}$, untuk menentukan unsur-unsur yang ada dalam berpikir kreatif dan untuk menentukan langkah-langkah dalam memecahkan suatu masalah khususnya kesebangunan dan simetri pada bangun datar.

\section{PEMBAHASAN}

Pengertian Berpikir

M. Ngalim Purwanto (2007:43-46) Berpikir adalah satu keaktifan pribadi manusia yang mengakibatkan penemuan yang berarah kepada satu tujuan. Ciriciri utama dari berpikir adalah adanya abstraksi. Abtraksi dalam hal ini berarti: anggapan lepasnya kualitas atau relasi dari benda-benda, kejadian-kejadian dan situasi yang mula-mula dihadapi sebagai kenyataan.

\section{Pengertian Kreatif}

Kreatif adalah kemampuan seseorang untuk melahirkan sesuatu yang baru, baik berupa gagasan maupun karya nyata, baik dalam bentuk karya baru maupun kombinasi dengan hal-hal yang 
sudah ada, yang belum pernah ada sebelumnya dengan menekankan kemampuan yaitu yang berkaitan dengan kemampuan untuk mengkombinasikan, memecahkan atau menjawab masalah dan cerminan kemampuan operasional anak kreatif (Gana Bima,2013).

\section{Prinsip Berpikir Kreatif}

Pehkonen dalam Isna Nur Lailatul Fauziyah1, Budi Usodo, Henny Ekana $\mathrm{Ch}(2013: 77)$ mengemukakan bahwa "Berpikir kreatif dapat diartikan sebagai suatu kombinasi dari berpikir logis dan berpikir divergen yang didasarkan pada intuisi tetapi masih dalam kesadaran." Dalam berpikir kreatif, seseorang dituntut untuk dapat memperoleh lebih dari satu jawaban terhadap suatu persoalan dan untuk itu maka diperlukan imajinasi. Sedangkan menurut Tatag Yuli Eko Siswono (2011:549) Creative thinking is the mental process which someone uses to come up with the "new" ideas as fluency and flexibility. "Idea" means a thought in solving and posing a problem.

Pikiran seseorang adalah sebuah penampang ide. Apa yang seseorang ketahui adalah jumlah total dari semua yang telah dipelajari dan dialami. Ide ada didalamnya dan seseorang hanya perlu membawa ide tersebut keluar dari otak. Tetapi seseorang tidak akan pernah bisa mengeluarkan semua ide tersebut tanpa sikap mental dan pendekatan yang tepat. Untuk berpikir secara kreatif seseorang hanya perlu mengkombinasikan kreativitas alamiah dengan sumber daya stimulus (pemacu otak) dan prinsip berpikir kreatif. Prinsip berpikir kreatif (Arthur B.Vangundy,1995,terjemahan Ati Cahayani,2011:18-36) diantaranya: Menciptakan pemisahan ide dari evaluasi

Prinsip ini merupakan prinsip terpenting dalam berpikir kreatif karena pemecahan masalah yang kreatif memerlukan pemikiran yang devergen dan konvergen.

Menguji asumsi
Dalam menguji asumsi pemacu otak menampilkan stimulus yang menggambarkan sejumlah respon. Respon khusus pada seseorang tergantung pada asumsi yang seseorang buat tentang stimulus tertentu. Semakin banyak seseorang menggunakan stimulus, semakin besar kemungkinan menghasilkan banyak ide. Ketika stimulus ini dan reaksi individu yang berbeda digunakan di dalam sebuah kelompok, kemungkinan jumlah dan kualitas ide meningkat. Semakin banyak stimulus dan semakin banyak orang akan terdapat lebih banyak asumsi dan pada akhirnya semakin banyak ide yang dihasilkan. Semakin banyak ide maka akan memberikan seseorang banyak pilihan dan peluang untuk memecahkan masalah. Alasan lain yang membuat penguji asumsi penting adalah hal itu bisa menghasilakan terobosan persepsi dan melihat pemahaman dengan pemahaman baru. Seperti yang pernah dikatakan filsuf Marcel Proust, "perjalanan yang sebenarnya untuk menemukan sesuatu, tidaklah pada pencarian sesuatu yang baru, tetapi mencari dengan mata baru".

Menghindari pemikiran yang berpola

Berpikir kreatif sering kali menuntut kita untuk melakukan suatu kebiasaan. Seperti pernah dikatakan oleh Charles Kettering, penemu starter listrik untuk mobil, "Seseorang tidak akan pernah mendapat ide dengan mempertahankan kebiasaan"

Untuk mematahkan pola, seseorang harus membuat suatu usaha yang disadari. Pertama, lebih memahami kebiasaan yang menghambat pemikiran kemudian, mengubahnya secara sengaja. Meminimalkan pemikiran negatif

Sebagian besar orang dalam melakukan sesuatu cenderung memikirkan resiko negatif ini dapat menghambat berpikir kreatif.

Menganbil resiko yang hati-hati

Tidak ada seseorang yang benar-benar berhasil tanpa kegagalan terlebih dahulu. Contoh, novelis John Creasey pernah mengalami penolakan sebanyak 75 kali sebelum dia menerbitkan 564 
buku. Oleh sebab itu pengambilan resiko tidaklah buruk. Karena pemacu otak melibatkan risiko penciptaan ide dan bukan penerapan.

Yudha (2004) dalam Euis Eti Rohaeti (2012:100) menyatkan bahwa "stated five steps of creative thinking those are: orientation of problem: formulate problem, and identify component of the problem; preparation: collecting relevant information to the problem, incubation: taking a rest for a moment, when problem solving process was stag, ilumination: looking for ideas and insight for solving problem; and verification: testing and assessing the solution critically".

Selain itu Utami Munandar (2009:65) menyatakan bahwa unsurunsur yang terdapat dalam berpikir kreatif dari Guilford diantaranya: Kelancaran dalam berpikir, kelenturan dalam berpikir, orisinalitas dalam berpikir dan kemampuan merinci (elaborasi).

Dari unsur-unsur berpikir kreatif di atas maka dapat dijabarkan sebagai berikut.

Kelancaran dalam berpikir meliputi dapat menemukan gagasan/ide. Penemuan gagasan/ide tersebebut dapat berkembang sehingga tidak hanya satu gagasan/ide yang akan ditemukan melainkan dapat menghasilkan lebih dari satu gagasan/ide.

Kelenturan dalam berpikir meliputi dapat memecahkan masalah dengan satu maupun berbagai cara, dapat melihat masalah dari berbagai sudut pandang yang ada dan dapat mengembangkan konsep dalam memecahkan suatu permasalahan secara sempurna.

Orisinalitas dalam berpikir meliputi dapat menciptakan gagasan baru dalam menyelesaikan suatu masalah.

Kemampuan merinci (elaborasi) meliputi dapat menguraikan gagasan secara terperinci.

Pengertian dan Hakekat Pemecahan Masalah

Pemecahan masalah adalah menggunakan (yaitu mentranfer) pengetahuan dan ketrampilan yang sudah ada untuk menjawab pertanyaan yang belum terjawab atau situasi yang sulit. Kreativitas seperti pemecahan masalah adalah salah satu bentuk tranfer, karena hal tersebut melibatkan pengaplikasian pengetahuan dan ketrampilan yang telah diketahui sebelumnya pada situasi yang baru. Banyak tugas yang komplek melibatkan baik pemecahan masalah maupun kreativitas. Namun kedua proses tersebut berbeda dalam hal bahwa pemecahan masalah melibatkan pemikiran konvergen, sedangkan kreativitas melibatkan pemikiran divergen (Jeanne Ellis Ormrod,2008,terjemahan Wahyu, Eka, Airin dan Puji,2009:393-406).

Pada dasarnya individu yang kreatif cenderung dalam memecahkan masalah melakukan hal-hal sebagai berikut (Jeanne Ellis Ormrod,2008,terjemahan Wahyu, Eka, Airin dan Puji,2009:407): 1) Menafsirkan masalah dan situasi secara flesibel Memiliki banyak informasi yang relevan dengan suatu tugas. 2) Mengkombinasikan informasi dan ideide yang ada dengan cara-cara yang baru. 3) Mengevaluasi pencapaian mereka menurut standar yang tinggi. 4) Menginvestasikan banyak waktu dan usaha dalam apa yang sedang mereka kerjakan.

Langkah-Langkah Menyelesaikan Pemecahan Masalah Matematika

Cara memecahkan masalah dikemukakan oleh beberapa ahli, di antaranya Dewey dan Polya. Dewey (dalam Rothstein dan Pamela 1990) memberikan lima langkah utama dalam memecahkan masalah sebagai berikut. a) Mengenali/menyajikan masalah: tidak diperlukan strategi pemecahan masalah jika bukan merupakan masalah. b) Mendefinisikan masalah: strategi pemecahan masalah menekan-kan pentingnya definisi masalah guna menentukan banyaknya kemungkinan penyelesian. c) Mengembangkan beberapa hipotesis: hipotesis adalah alternatif penyelesaian dari pemecahan 
masalah. d) Menguji beberapa hipotesis: mengevaluasi kele-mahan dan kelebihan hipotesis. Memilih hipotesis yang terbaik.

Sebagaimana Dewey, Polya (1985) pun menguraikan proses yang dapat dilakukan pada setiap langkah pemecahan masalah. Proses tersebut terangkum dalam empat langkah berikut. 1) Memahami masalah (understanding the problem). 2) Merencanakan penyelesaian (devising a plan). 3) Melaksanakan rencana (carrying out the plan). 4) Memeriksa proses dan hasil (looking back).

Berangkat dari pemikiran yang dikemukakan oleh ahli tersebut, maka untuk menyelesaikan masalah diperlukan kemampuan pemahaman konsep sebagai prasyarat dan kemampuan melakukan hubungan antar konsep dan kesiapan secara mental. Pada sisi lain berdasarkan pengamatan Soleh (1998), salah satu sebab siswa tidak berhasil dalam belajar matematika selama ini adalah siswa belum sampai pada pemahaman relasi (relation understanding), yang dapat menjelaskan hubungan antar konsep. Hal itu memberikan gambaran kepada kita adanya tantangan yang tidak kecil dalam mengajarkan pemecahan masalah matematika.(Ahmad Firdaus:2009). Selain itu menurut Zheng Zhu (2007) "a mathematical problem solver not only required cognitive abilities to understand and represent a problem situation, to create algorithms to the problem, to process different types of information, and to execute the computation, but also had to be able to identify and manage a set of appropriate strategies (heuristics, techniques, shortcuts etc.) to solve the problem".

\section{HASIL PENELITIAN}

Hasil Analisis Kemampuan Siswa Berdasarkan Analisis Kesalahan yang dibuat. Berdasarkan analisis kreativitas siswa yang dibuat dalam tes tertulis maupun wawancara dapat diketahui bagaimana kemampuan siswa dalam menyelesaikan permasalahan kesebangunan dan simetri pada bangun datar, antara lain sebagai berikut. Siswa yang berkategori tinggi. a) Dalam memahami masalah, Tidak ada kesalahan dalam memahami masalah, ini berarti siswa mampu untuk memahami masalah dengan baik. b) Dalam merencanakan penyelesaian Tidak ada kesalahan dalam merencanakan penyelesaian, ini berarti siswa mampu untuk merencanakan penyelesaian dengan baik. c) Dalam melaksanakan rencana Sebagian siswa tidak ada kesalahan dalam menyelesaikan masalah sesuai rencana sebagian lagi ada kesalahan dalam menyelesaikan masalah sesuai rencana, ini berarti tidak semua siswa berkategori tinggi mampu untuk menyelesaikan masalah sesuai rencana dengan baik. d) Dalam memeriksa proses dan hasil Siswa kurang teliti dalam memeriksa proses dan hasil sehingga gagasan yang terurai kurang terperinci. Siswa yang berkategori sedang. Dalam memahami masalah. Tidak ada kesalahan dalam memahami masalah, ini berarti siswa mampu untuk memahami masalah dengan baik. Dalam merencanakan penyelesaian. Tidak ada kesalahan dalam merencanakan penyelesaian, ini berarti siswa mampu untuk merencanakan penyelesaian dengan baik. a) Dalam melaksanakan rencana Ada kesalahan dalam menyelesaikan masalah sesuai rencana, ini berarti siswa mempunyai kemampuan yang kurang baik dalam menyelesaikan masalah sesuai rencana. b) Dalam memeriksa proses dan hasil Siswa kurang teliti dalam memeriksa proses dan hasil sehingga gagasan yang terurai kurang terperinci. Siswa yang berkategori rendah. Dalam memahami masalah Ada kesalahan dalam memahami masalah, ini berarti siswa mempunyai kemampuan yang kurang baik dalam memahami masalah. Dalam merencanakan penyelesaian. Tidak dapat membuat rencana penyelesaian untuk seluruh soal, ini berarti siswa tidak mampu untuk merencanakan 
penyelesaian seluruhnya. Dalam melaksanakan rencana Siswa tidak bisa membuat penyelesaian masalah seluruhnya hanya sebagian soal yang dapat dibuat penyelesaian masalah, ini berarti siswa tidak mampu untuk melaksanakan rencana dikarenakan siswa mengalami kesulitan dalam memahami konsep kesebangunan dan simetri pada bangun datar. Dalam memeriksa proses dan hasil Siswa kurang teliti dalam memeriksa proses dan hasil sehingga gagasan yang terurai kurang terperinci.

\section{SIMPULAN DAN SARAN}

\section{Kesimpulan}

Berdasarkan pembahasan dan anallisis data dari hasil penelitian yang telah dilakukan pada siswa kelas V SD N Rejomulyo, maka dapat disimpulkan sebagai berikut. 1) Siswa kategori tinggi memiliki kecenderungan yang sedang dalam memeriksa proses dan hasil. Sedangkan untuk tahapan kreativitas yang lain siswa tergolong baik yaitu siswa mampu memahami masalah, merencanakan penyelesaian masalah dan melaksanakan rencana penyelesaian masalah dengan tepat dan benar dalam menyelesaikan masalah kesebangunan dan simetri pada bangun datar. Siswa kategori sedang memiliki kecenderungan yang sedang dalam tahapan kreativitas yaitu siswa mampu memahami masalah, merencanakan penyelesaian masalah, melaksanakan rencana penyelesaian masalah dan memeriksa proses dan hasil sehingga siswa dapat menyelesaikan soal kesebangunan dan simetri pada bangun datar dengan cukup runtut walaupun ada yang kurang tepat. 2) Siswa kategori rendah memiliki kecenderungan yang sedang dalam menguraikan jawaban secara terperinci. Sedangkan untuk tahapan kreativitas yang lain siswa tergolong kurang yaitu siswa belum mampu memahami masalah, siswa belum mampu merencanakan penyelesaian masalah dan siswa belum mampu dalam melaksanakan rencana penyelesaian masalah kesebangunan dan simetri pada bangun datar dengan tepat dan benar.

\section{Saran}

Berdasarkan kesimpulan, beberapa saran yang perlu disampaikan adalah bagi guru diharapkan membantu siswa agar dapat mengembangkan atau menciptakan kreativitas siswa dan meningkatkan aktivitas belajar matematika siswa, agar bertambah dan mampu membantu keberhasilannya. Bagi pengembang penelitian diharapkan memberikan dukungan positif terhadap pengembangan ilmu pengetahuan pada umumnya dan dunia pendidikan pada khususnya. Bagi siswa diharapkan dapat menumbuhkan kreativitas secara maksimal sehingga mampu mampu meningkatkan prestasi belajarnya di sekolah.

\section{DAFTAR PUSTAKA}

Ahmad Firdaus.2009.Kemampuan Pemecahan Masalah Matematika,(online),(http://madfi rdaus.wordpress.com/2009/11/23/ kemampuan- pemecahanmasalah-matematika/,Diunduh 14 Januari 2013).

Arthur B. Vangundy.1995.Cara Mendapatkan Ide-ide Kreatif dan Cemerlang. Terjemahan oleh Ati Cahayani. 2011. KembanganJakarta Barat: Indeks.

Buchoro,Ana dan

Erna.2012.Ensiklopedia

Matematika.Semarang:PT.Benga wan Ilmu.

Carol R.Aldous.2010.Creativity in Problem Solving. International Education Journal (Online), Jilid 5,No.5, (http://ehlt.flinders.edu.au / education / iej / articles / v5n5 / aldous / paper.pdf).

Euis Eti Rohaeti.2010. Critical and Creative Mathematical Thinking of Junior High School Students.Educastionist (Online), Jilid IV, No.2, 
(http://file.upi.edu/Direktori/JUR NAL/EDUCATIONIST/Vol._IV

No. 2-

Juli_2010/05_Euis_Eti_Rohaeti.p df).

Gana Bima Usaha.2013.Daya Cipta (Kreatif),(online),(www.labschool

$=$

unj.sch.id/smpjkt/materi_downloa d.php? $i d=7$, Diunduh 06 Januari 2013).

Isna Nur Lailatul Fauziyah, Budi Usodo, Henny Ekana Ch.2013.Proses Berpikir Kreatifr Siswa Kelas $X$ dalam Memecahkan Masalah Geometri Berdasarkan Tahapan Wallas Ditinjau dari Adversity Quotient (AQ) Siswa.Jurnal Pendidikan Matematika Solusi (Online), Jilid

1,No.1,(http://jurnal.fkip.uns.ac.i d/index.php/matematika/article/ download/676/1083)

Jeanne Ellis Ormrod.Tanpa Tahun.Psikologi Pendidikan Membantu Siswa Tumbuh dan Berkembang.Terjemahan oleh Wahyu, Eva, Y.Saleh dan Puji.2008.Jakarta:Erlangga.

L.J.Moleong.2007.Metode Penelitian Kualitatif.Bandung:PT Remaja Rosdakarya.

Marsigit.2012.Kajian Penelitian (Review Jurnal Internasionam) Pendidikan Matematika.Jurnal Internasional ( Online), (http: //staff.uny.ac.id/_ sites/ default/files/pendidikan/Marsigit, \%20Dr.,\%20M.A./Kajian\%20Pen elitian\%20(Review\%20Jurnal\%2 0Internasional)\%20Pendidikan $\% 2$ OMatematika_Matrikulasi\%20S2 \%20Dikmat.pdf, Diunduh 17 April 2013)

Michael Quinn Patton.1991.Metode Evaluasi Kualitatif.Terjemahan oleh Budi Puspo

Priyadi.2009.Yogyakarta:Pustaka Pelajar.

M. Khalif dan Suyati.2002.Pelajaran Matematika Penekanan pada Berhitung Jilid 5.Jakarta: Erlangga.

M.Ngalim Purwanto.2007.Psikologi Pendidikan.Bandung:PT Remaja Rosdakarya

Sanapiah Faisal.2010.Format-format Penelitian Sosial.Jakarta:PT Rajagrafindo Persada.

Slameto (Ed.).2010.Belajar dan Faktorfaktor yang Mempengaruhi.Jakarta: Rineke Cipta.

Sri Marsidah Handayani.2009.Pola Alih Kode Dalam Interaksi Jual Beli di Pasar Tradisional Kota Lumajang.Skripsi ini tidak diterbitkan.Malang: Program Studi Pendidikan Bahasa dan Sastra Indonesia Universitas Wisnuwhardana.

Sugiyono.2012.Memahami Penelitian Kualitatif.Bandung:Alfabeta.

Tatag Yuli Eko Siswono.2011. Level of student's creative thinking in classroom Mathematics. Educational Research and Review (Online),Jilid 6,No.7, (http://www.academicjournals.org lerr/PDF/Pdf\%202011/July/Siswo nopdf)

Utami Munandar.2009.Pengembangan Kreativitas Anak Berbakat.Jakarta: Rineke Cipta.

Zheng Zhu.2007.Gender differences in mathematical problem solving patterns: A review of literature.International Education Journal (Online),Jilid 8, No.2, (http://ehlt.flinders.edu.au/educati on/iej/articles/v8n2/Zhua/paper.pd f) 